TAPROBANICA, ISSN 1800-427X. December, 2013. Vol. 05, No. 02: pp. 140-141, 1 pl.

(C) Taprobanica Private Limited, 146, Kendalanda, Homagama, Sri Lanka.

http://www.sljol.info/index.php/tapro

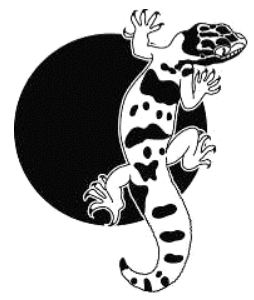

\section{Rediscovery of Mallotus intercedens (Euphorbiaceae)}

The genus Mallotus Lour. is a large and complex paleotropical genus of about 150 species and are mainly distributed in Asia, Africa and Australasia to Fiji (Webster 1994). In India it is represented by 17 species, of which Kerala harbours 12 species including two varieties (Balakrishnan \& Chakrabarty 2007; Nayar et al. 2006).

During the survey and ex-situ conservation of the rare, endangered and threatened plants of the Western Ghats, Mallotus intercedens Pax \& K. Hoffm. was collected from the Palaruvi forests of Kollam district in Kerala state. It was originally proposed by Ferdinand Albin Pax and Kaethe Hoffmann in 1914 based on the collection of Robert Wight in 1836 from the Courtallum hills. Gamble had studied the type material (Wight 2669) housed at $\mathrm{K}$ and he expressed his doubt "......whether it is distinct from $M$. rhamnifolius". The original collection is represents only by male flowers. This made Gamble (1925) excluded this species from his Flora Presidency of Madras. Our discovery of plants with female flowers and fruits not only represents a rediscovery of this little-known species after a period of 176 years of its first collection, but it also allows us to declare that the species is distinct and worthy of recognition.

Mallotus intercedens Pax \& K. Hoffm. 1914. (Fig. 1).

In: H.G.A. Engler, Pflanzenr., IV(147) 7: 179. 1914.

Shrubs or small trees to $4 \mathrm{~m}$ high; twigs slender, shortly fulvous-pubescent when young and later glabrescent. Leaves alternate or subopposite, $5-15 \times 2-6 \mathrm{~cm}$; petiole $1.5-5 \mathrm{~cm}$ long, slender, pubescent; stipules short, lanceolate-subulate, caduceus; leaf blade elliptic-lanceolate or lanceolate, obtuse and cuspidate at apex, obtuse at base, entire at margins, glabrous except the nerves above, stellately tomentose to densely glandular beneath, rarely glaucous underneath, 3-nerved from the base on lower $1 / 3$ of the lamina with 4-5 pairs, alternate or subopposite lateral nerves and reticulated tertiary nerves. Inflorescence usually terminal or rarely on axillary spikes, shortly peduncled with glomerules of flowers with either many staminate flowers or with 10-25 pistillate flowers. Staminate inflorescence $7-12 \mathrm{~cm}$ long; rachis shortly tomentellous; bracts triangular, $1 \mathrm{~mm}$ long, each with 3-5 flowers; pedicels to $1.5 \mathrm{~mm}$ long, shortly tomentellous; flowers greenish yellow, in interrupted clusters often arising from the base, rarely on a peduncle up to $5 \mathrm{~cm}$ long. Stamens 55-65; connective greatly enlarged, truncate. Pistillate inflorescence in axillary and terminal spikes, 8-14 cm long; ovary sparsely echinate; style elongate. Fruits depressed, globose, capsules, short stellate hairy.

Specimens examined: Kulathupuzha, 200 m, Kollam District, Kerala, India, 25 Mar 2004, M.P. Geethakumary \& A.G. Pandurangan (TBGT, 54335); Palaruvi, $350 \mathrm{~m}, 04 \mathrm{Mar}$ 2005, M.P. Geethakumary \& A.G. Pandurangan (TBGT, 55392); ibid, 09 Apr 2012, E.S. Santhosh Kumar (TBGT, 70434).

Flowering and Fruiting: February-June

Distribution: Endemic to the southern Western Ghats regions of Kerala and Tamil Nadu at altitudes between $200-450 \mathrm{~m}$.

Habitat and ecology: In its present locality Mallotus intercedens is represented by about 60 individuals of different ages in a semievergreen forest along the side of a stream. The commonly associated species are Tetrameles nudiflora R.Br. (Datiscaceae), Atalantia racemosa Wight ex Hook. (Rutaceae), Phyllochlamys spinosa Bureau (Moraceae), Terminalia bellirica (Gaertn.) Roxb. 
(Combretaceae), Stereospermum chelonoides (L.f.) DC. (Bignonicaeae), etc.

Note: Mallotus intercedens is often confused with M. rhamnifolius (Willd.) Müll.Arg., but differs from that species by having tomentellous, lanceolate or elliptic-lanceolate leaves with a cuspidate apex, and male flowers with some 60 stamens.

\section{Acknowledgements}

The authors are grateful to the Director, JNTBGRI for the facilities provided and to the Kerala Forest Department for the logistic supports.

\section{Literature Cited}

Balakrishnan, N. P. and T. Chakrabarty, 2007. The Family Euphorbiaceae in India. Bishen Sigh Mahendrapal Singh, Dehra Dun: 143-152.

Gamble, J. S., 1925. Flora of the Presidency of Madras 2. Adlard \& Sons, London: 1319-1323.

Pax, F. and K. Hoffmann, 1914. Euphorbiaceae: Acalypheae-Mercurialinae. In: H.G.A. Engler (ed.). Das Pflanzereich IV(147) 7. W. Engelmann, Leipzig \& Berlin.

Webster, G. L., 1994. Synopsis of the genera and suprageneric taxa of Euphorbiaceae. Annals of the Missouri Botanical Garden, 81: 33-144.

Submitted: 25 Oct. 2013, Accepted: 18 Nov. 2013 Sectional Editor: James L. Reveal

E. S. S. Kumar ${ }^{1,2}$, M. P. Geethakumary ${ }^{1} \&$ A.G. Pandurangan ${ }^{1}$

${ }^{1}$ Jawaharlal Nehru Tropical Botanic Garden \& Research Institute, Palode, Thiruvananthapuram District, Kerala 695562, India. E-mail: santhoshkumares@gmail.com² 


\section{PLATE 4}
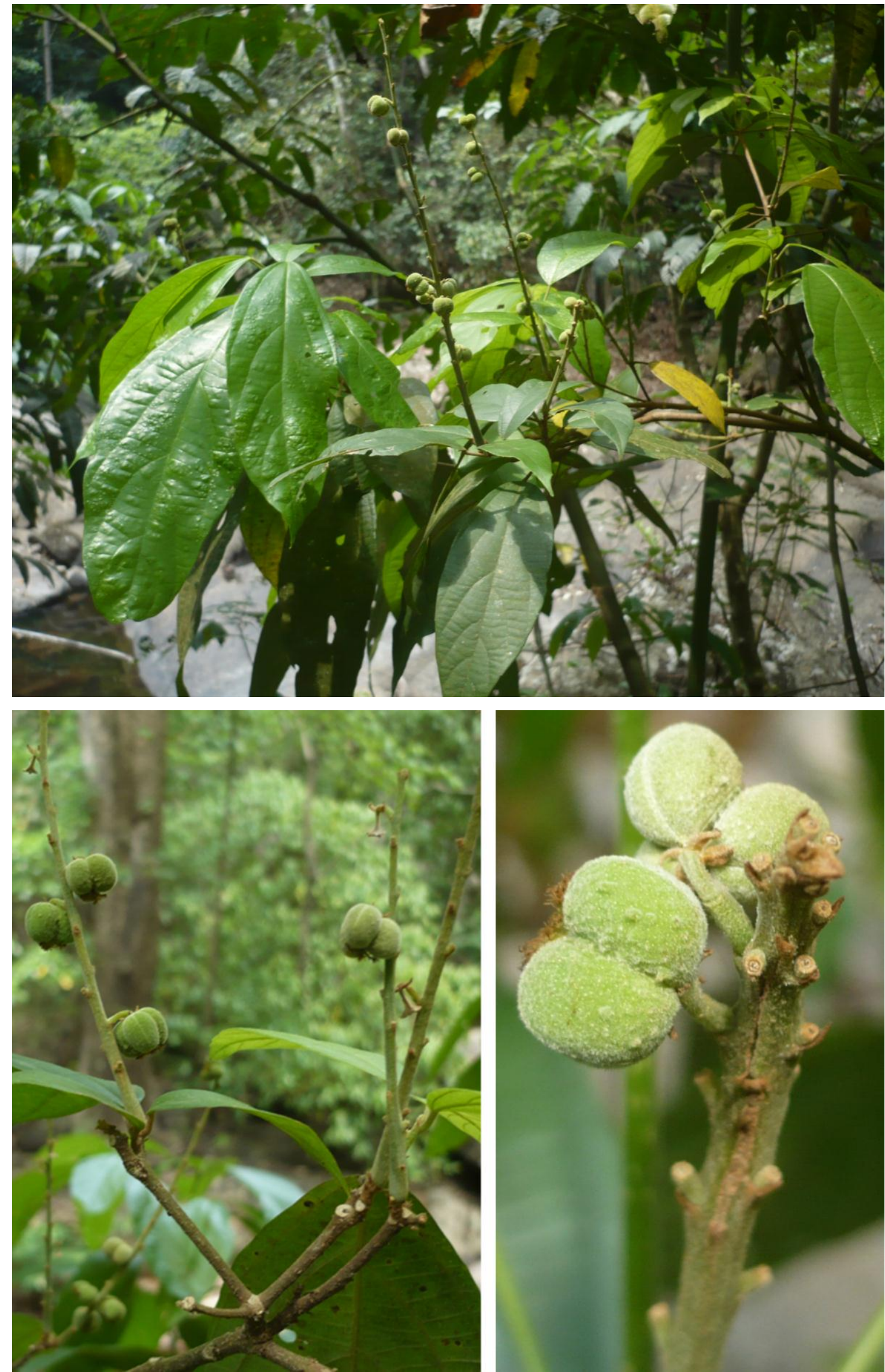

Figure 1: Mallotus intercedens Pax \& K. Hoffm. A, Plant in its natural habitat; B, Close up of a female infructescence; C, Close up of fruits. 